\title{
Relationship between CEO remuneration and company financial performance in the South African retail and consumer goods sector
}

\author{
Authors: \\ Mark Bussin ${ }^{1}$ \\ Morne $\mathrm{Nel}^{2}$ \\ Affiliations: \\ ${ }^{1}$ Industrial Psychology \\ and People Management, \\ University of Johannesburg, \\ South Africa \\ ${ }^{2}$ Gordon Institute of Business \\ Science, University of \\ Pretoria, South Africa \\ Correspondence to: \\ Mark Bussin \\ Email: \\ drbussin@mweb.co.za \\ Postal address: \\ PO Box 2334, Saxonwold \\ 2132, South Africa

\section{Dates:} \\ Received: 07 Nov. 2013 \\ Accepted: 30 Sept. 2014 \\ Published: 20 Apr. 2015 \\ How to cite this article: \\ Bussin, M. \& Nel, M., 2015, \\ Relationship between CEO \\ remuneration and company \\ financial performance in \\ the South African retail and \\ consumer goods sector', \\ Acta Commercii 15(1), Art. \\ \#240, 11 pages. http://dx.doi. \\ org/10.4102/ac.v15i1.240

\section{Copyright:} \\ C 2015. The Authors. \\ Licensee: AOSIS \\ OpenJournals. This work is \\ licensed under the Creative \\ Commons Attribution \\ License.
}

Read online:

Scan this QR code with your smart phone or mobile device to read online.
Purpose: This study was motivated by the need to better understand the effects of the global financial crisis in 2008 on the relationship between company financial performance and CEO guaranteed cost to company (CTC). The aim of this study was to understand the relationship between company financial performance using DuPont analysis and CEO guaranteed CTC in the South African retail and consumer goods sector.

Design: The research was a quantitative, archival study of companies listed on the Johannesburg Stock Exchange (JSE), measured over a period of six years (2006-2011). The statistical analysis included regression and correlation analysis.

Findings: The research found that CEO guaranteed CTC has shown no sensitivity towards company financial performance in terms of DuPont analysis over the six-year period, which included the global financial crises in 2008. Furthermore, a negative relationship existed between the return on equity and the guaranteed CTC of CEOs in the retail and consumer goods sector during this period.

Practical implications: The findings suggest that there is misalignment between company strategy and performance and the guaranteed CTC of CEOs. A practical implication would be to have independent and competent remuneration committees ensuring alignment of the interests of a company with those of its leaders in this regard.

\section{Introduction}

This study looked at the relationship between company financial performance and CEO fixed pay in the South African retail and consumer goods sector.

\section{Context}

Exorbitant executive remuneration and the link between equity incentives and company performance have enjoyed wide academic attention. However, the fixed pay spoke of the executive remuneration wheel goes mainly unnoticed in the literature (Frydman \& Jenter 2010). The South African retail sector was hard hit from the onset of the financial crisis of 2008 (Englund \& MacDonald 2008). Englund and MacDonald (2008) reported that retail sales in September of 2008 declined by $1.2 \%$. This negative influence on the retail sector continued throughout the crisis. Company turnover in the retail sector was negatively influenced, having a negative effect on return on equity (ROE).

Since the early 2000s executive compensation levels have increased dramatically. Managerial power and optimal contracting have been offered as leading reasons for this increase (Frydman \& Jenter 2010). Optimal contracting is defined as occurring when the three types of agency costs (contracting, monitoring and misbehaviour) are balanced against one another to minimise the total cost (Harvey 2012). It is suggested that executives have influenced remuneration committees to increase fixed pay (despite poor company performance over the financial crisis period) in order to compensate for the loss of short-term and long-term incentive payouts (Frydman \& Jenter 2010). Through managerial power, CEOs are able to influence boards and compensation committees and thus influence the structure of their remuneration packages (Doscher \& Friedl 2010).

\section{Problem statement}

The problem with short-term incentives is that they are linked to the financial performance of the company; because of the inability of companies to perform during the financial crisis, the 
total remuneration packages of CEOs should have decreased (Bussin, Makhubela \& Quail 2009). Various theories such as the principal-agent theory and managerial power suggest that the CEO could influence their guaranteed cost to company (CTC) to a point where it becomes misaligned with the financial performance of the company in order to 'plug the gap' left by a decrease in the short-term incentive portion (21st Century Pay Solutions Group 2011). If this relationship between guaranteed CTC of the CEO and company financial performance is not understood, the remuneration of the CEO might become misaligned to the strategic direction of the company thus the CEOs' pay will not reflect their performance.

\section{Remuneration constructs}

A remuneration package has various levels: salary, annual bonus, long-term and short-term performance incentives (Frydman \& Jenter 2010).

Figure 1 illustrates how the financial reward system can be segmented (21st Century Pay Solutions Group 2011).

Well-designed incentives or variable packages should be linked to the financial performance of the company. Equity exposure will ensure long-term wealth creation as the main objective for a CEO, because of the link created between the goal and their efforts. Whilst it is clear that welldesigned incentives or variable packages should be linked to the financial performance of the company, the issue of guaranteed CTC pay solutions for CEOs is more complex and open to distortion. It thus warrants further investigation (Hoi \& Robin 2004).

The remuneration concept has various constructs (Ellig 2007):

- 'Salary': guaranteed pay that the executive will receive, which is normally a risk-free monthly payment.

- 'Benefits and perquisites': constructs such as health care, survivor protection and retirement funds.

- 'Short-term incentives': cash payments for achieving of short-term and standard annual goals and objectives.

- 'Long-term incentives': multi-yearly; could include equity-based payments.

Further definitions (21st Century Pay Solutions Group 2011):

- 'Fixed-pay': salary and benefits, all guaranteed components of the remuneration package.

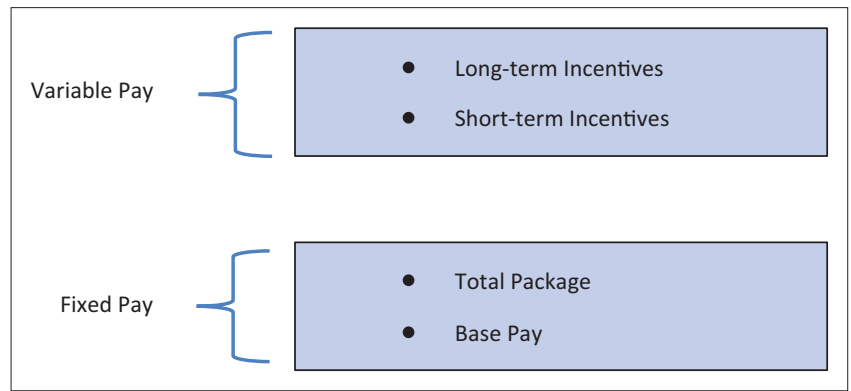

FIGURE 1: Total reward.
- 'Total remuneration' or 'total cost of employment': fixed pay and short-term incentives.

- 'Total earnings' or 'total cost to company': fixed pay and all incentives.

In this study the definition of fixed pay or guaranteed CTC (fixed salary and benefits) will be used (McGregor 2011).

\section{The DuPont model}

The financial performance of a company can be measured by evaluating its financial statements over a period of time. Higgins (2009) argues that the levers of financial performance are the same for all companies. This makes accurate comparison of the financial performance of companies possible. The levers of financial performance can be combined into one ratio, the ROE ratio (Higgins 2009):

$$
\begin{aligned}
\text { ROE }= & \text { Net Income/Sales } \times \text { Sales/Assets } \\
& \times \text { Assets } / \text { Shareholders }{ }^{\prime} \text { Equity }
\end{aligned}
$$

This formula for the evaluation of financial performance is called the DuPont model. There is a connection between this model and a company's achievement of its competitive advantage (Little, Little \& Coffee 2009). Rollins (2006) states that the DuPont model is an effective measure of how well a company is being managed. Soliman (2008) observed the historical DuPont analysis of various companies and then compared current financial performance to the constructs of the model, with specific reference to asset turnover. He found a positive correlation between these constructs including future share price performance. This suggests that CEOs who are able to manage the constructs of DuPont analysis are best positioned to create future value for both the company and its shareholders. The decision to use the DuPont model for analysis of the relationship between company financial performance and CEO remuneration was based on the way in which the model includes strategic decisions and the performance of management into the assessment of the financial performance of a company.

\section{The principal-agent theory}

The principal-agent theory needs to be understood in order to gain an understanding of the executive remuneration process. Laffont and Martimort (2002) argue that the owner of a company needs to delegate their responsibilities to other members of the company. The owner therefore becomes the principal and the employee becomes the agent. Duffhues and Kabir (2007) mention that listed companies are characterised by the ownership of the company residing with the shareholders who reflect a diverse and wide cross-section of the population, whilst control is in the hands of a few managers responsible for the management of the company. The principal-agent theory infers that these managers or agents do not always perform their jobs solely in the best interests of the shareholders. Frydman and Jenter (2010) discuss executive pay as a possible method of rectifying this misalignment between the principal and the agent. 
Compensation committees are one of the key mechanisms that could assist in aligning the principal and the agent by reviewing CEO compensation with specific attention to goal setting and the alignment to incentives (Heim 2011). O'Reilly and Main (2010) describe this process as the board crafting an optimal pay mechanism to try to align the interests of the CEO with those of the shareholders. Thus it is clear that the CEO is the agent of the shareholders who, as a group, represent the principal and that the agent's goals should be aligned with those of the company and the principal.

\section{Remuneration committees}

The principal-agent theory assumes it is the purpose of the board to monitor the CEO. However, O'Reilly and Main (2010) argue that this is a very narrow view of the duties of a board. To minimise the costs associated with this theory, CEO compensation should be linked to both the CEO's performance and the company's performance to ensure an alignment between shareholders and management interests (O'Reilly \& Main 2010). Prior research has shown that as the power of the CEO increases their pay increases; however, the sensitivity of their pay to performance decreases ( $\mathrm{O}^{\prime}$ Reilly \& Main 2010). The King report (King Committee 2009) discusses the remuneration committee in detail and adds that it should be the duty of the remuneration committee to assist the board in setting the various salary bands within the company, particularly for the remuneration packages of the senior executives. The King report (King Committee 2009) states that remuneration committees should keep the long-term goals of the company in mind when giving remuneration advice.

\section{Executive remuneration}

The concept of executive remuneration includes all payments made to executive members of the board, including the CEO (Bussin 2010). These payments include all guaranteed CTC, short-term and long-term incentives and other financial benefits for performance rendered (Bussin 2010). Desirable remuneration packages are created to ensure the ability of the company to attract and retain the best possible CEOs. The most common determinants for executive pay are organisation size, organisation performance, executivespecific factors (such as age, experience, tenure and career path), organisation structure, job or position-specific factors and job complexity (Bussin 2010). Ellig (2007) argues that the structure of an executive's remuneration package will follow the path along which it is easiest for the executive to earn. Should short-term incentives be difficult to obtain due to factors outside the control of the CEO, the structure of the remuneration would lean towards a guaranteed CTC or fixed pay. The inverse is also true: should short-term incentives be easier to obtain, the structure of remuneration will gravitate towards higher incentive pay (Ellig 2007). The global trend is to cut or suspend short-term, long-term and incentive bonuses (Bussin et al. 2009). The South African trend for upper and middle management mirrors this, showing the trimming of benefits and bonuses (Bussin et al. 2009).
This highlights the need to better understand the guaranteed CTC of CEOs and how this is aligned to the determinants of executive remuneration structure. This is supported by the research done on Dutch listed companies, where a strong negative relationship between CEO guaranteed CTC and company performance was found (Duffhues \& Kabir 2007). This result was attributed to managerial power and the inability of independent board members and compensation committees to design an effective compensation strategy (Duffhues \& Kabir 2007).

\section{Research design and objectives}

This research was quantitative and used secondary, documentary text data to analyse the correlation between the above-mentioned constructs.

\section{Research objectives}

- To determine the relationship between the various constructs of ROE: profit margin, asset turnover, financial leverage and the guaranteed CTC of CEOs in the retail and consumer goods sector.

- To determine the relationship between overall ROE and the guaranteed CTC of CEOs in the retail and consumer goods sector.

- To determine the relationship between the consumer pricing index (CPI) and guaranteed CTC of CEOs in the retail and consumer goods sector during the research period (2006-2011).

- To investigate the relationship between the guaranteed CTC of CEOs in the period before (2006-2008) and after (2009-2011) the financial crisis.

\section{Research design}

A literature review was conducted to find the appropriate financial performance measures. DuPont analysis was selected to measure company financial performance. This study was a desktop study of secondary time series data in the public domain. All data used was audited as per JSE Listing Requirement 3.19(b) (JSE 2013). The data were gathered from financial data that had been reported over a period of six years. The six years covered the full business cycle, with growth between 2006 and 2007, a recessionary decline in 2008 and recovery from 2009 through to 2011. The data were statistically analysed to determine the relationship between company financial performance and CEO guaranteed CTC.

\section{Universe}

The universe for this study included all companies on the JSE in the retail and consumer goods sector over the period of 2006 to 2011 (Saunders \& Lewis 2012). The retail sector was chosen because of the financial challenges it faced and still faces due to the financial crisis (Elliott 2011). From the beginning of the financial crisis in 2008, the South African retail sector was hard hit. Englund and MacDonald (2008) reports that retail sales in September of 2008 declined by 
TABLE 1: Census: list of companies.

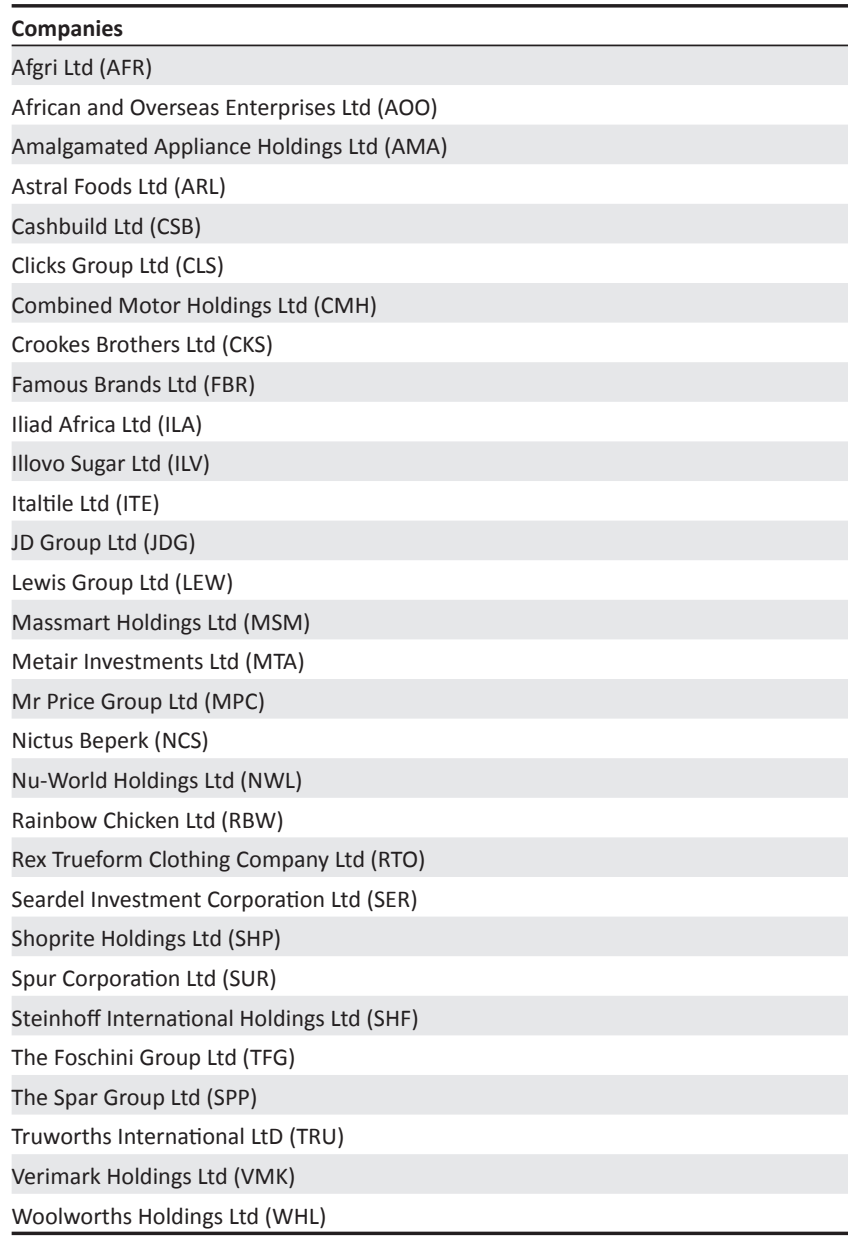

$1.2 \%$, with consumer spending already making a 'U-turn' in mid-July of that year. This negative influence on the retail sector continued throughout the crisis.

This universe was also chosen because of the fiduciary regulations that require listed companies to submit publicly accessible, audited financial statements that include the remuneration of its CEOs, which data were necessary to construct the DuPont analysis.

\section{Unit of analysis}

The data used to determine the CEOs' pay was the guaranteed CTC of the CEO. Incentives, short-term and long-term, and bonuses were excluded. Company financial performance was measured using DuPont analysis and its various constructs: ROE, asset turnover, leverage and CPI.

\section{Data collection and analysis}

Data were collected from databases containing secondary historical company financial information (McGregor 2011). In the event of data being incomplete individual companies' annual financial reports were used to complete the data set. These annual financial reports were available from company websites or directly in accordance with JSE regulations. The statistical analysis of the data was done in the form of a simple regression analysis to determine the relationship between the dependent variable (guaranteed CTC) and the explanatory variable (company financial performance), expressed as follows:

Guaranteed CTC $=\beta \mathrm{o}+\beta_{1}$.company financial performance . $_{\chi}$ Eqn 2]

This was followed by a multiple regression analysis:

Guaranteed CTC $=\beta \mathrm{o}+\beta_{1}$. company financial performance $e_{\chi}$ $+\cdots+\beta_{\mathrm{v}}$.company financial performance $\mathrm{v}_{\mathrm{v}}[$ Eqn 3]

Repeated measures analysis of variation was used to compare the means of various groups and the explained and unexplained variances. The $F$-ratio was used to describe the level of significance.

\section{Research hypotheses}

- Research hypothesis 1: There is a correlation between the financial performance and the guaranteed CTC of CEOs in terms of the DuPont analysis for retail and consumer goods companies listed on the JSE, for the period of 2006-2011.

- Research hypothesis 2: There is a correlation between ROE and guaranteed CTC of CEOs of retail and consumer goods companies listed on the JSE, for the period of 2006 to 2011.

- Research hypothesis 3: There is a relationship between the South African CPI and the guaranteed CTC of CEOs of retail and consumer goods companies listed on the JSE, for the period of 2006-2011.

- Research hypothesis 4: There is a relationship between guaranteed CTC of CEOs in the retail and consumer goods sector before the financial crisis (2006-2008) and after the financial crisis (2009 to 2011).

Cognisance is taken of the CPI when organisations are setting their budgets for the following year. This is especially so when setting budgets for the annual salary and wage bill (Bussin 2010). The relationship between CEO CTC and CPI is of interest in the context of the present study because the authors wanted to see if indeed CEO CTC moved up at a similar rate to the CPI.

\section{Research limitations}

Due to the nature of the study and the time constraints of the research project, the following have been identified as research limitations:

- The research does not take into account the casual factors that influence the pay-for-performance relationship.

- The research does not take into consideration the appointment of new executives or the replacement of exiting executives, which might have been at a higher salary.

- Six years may not be sufficient to analyse the relationship between pay performance and a company's financial performance. 


\section{Results \\ Descriptive statistics}

The census group included 30 companies from the retail and consumer goods sector listed on the JSE for the research period. During the research period, 42 CEOs headed up these companies. Of the sample group a total of $63 \%$ (19) had one CEO and the remaining 37\% (11) had more than one CEO during the research period.

\section{Measures of company financial performance}

Company financial performance was measured using DuPont analysis:

ROE $=$ Net income/Sales $\times$ Sales/Assets $\times$ Assets/Shareholder's equity

[Eqn 4]

Table 2 shows the mean of the sample for each of the constructs of company financial performance during the research period.

Table 3 indicates the standard deviation for the constructs of the DuPont analysis over the research period.

\section{Leverage}

The leverage mean can be approximated with a cubic curve, with a fit of 0.7396 . There is no clear trend in an upward or downward direction. Therefore, to see a measure of average company financial performance over time, the three levers need to be combined into the ROE. See Figure 2.

The leverage mean reached a high of 2.24 in 2008, declined steeply to pre-recession levels of 2.14 and showed an upward trend in 2011.

\section{Net margin}

The net margin mean can be approximated with a quadratic curve, with a fit of 0.7607 . See Figure 3.

TABLE 2: Company financial performance (mean).

\begin{tabular}{lcccc}
\hline Year & Return on equity (\%) & Asset turnover & Net margin (\%) & Leverage \\
\hline 2006 & 25.61 & 2.08 & 8.49 & 2.17 \\
2007 & 24.81 & 2.05 & 8.46 & 2.22 \\
2008 & 21.33 & 2.09 & 7.05 & 2.23 \\
2009 & 19.05 & 2.12 & 6.68 & 2.22 \\
2010 & 20.49 & 2.05 & 7.22 & 2.14 \\
2011 & 21.28 & 2.03 & 8.46 & 2.19 \\
\hline
\end{tabular}

TABLE 3: Company financial performance (standard deviation).

\begin{tabular}{lcccc}
\hline Year & Return on equity (\%) & Asset turnover & Net margin (\%) & Leverage \\
\hline 2006 & 13.42 & 1.09 & 7.12 & 1.23 \\
2007 & 13.61 & 1.07 & 8.16 & 1.26 \\
2008 & 15.09 & 1.10 & 7.33 & 1.28 \\
2009 & 15.20 & 1.15 & 7.42 & 1.45 \\
2010 & 11.67 & 1.18 & 5.63 & 1.41 \\
2011 & 16.66 & 1.21 & 8.61 & 1.53 \\
\hline
\end{tabular}

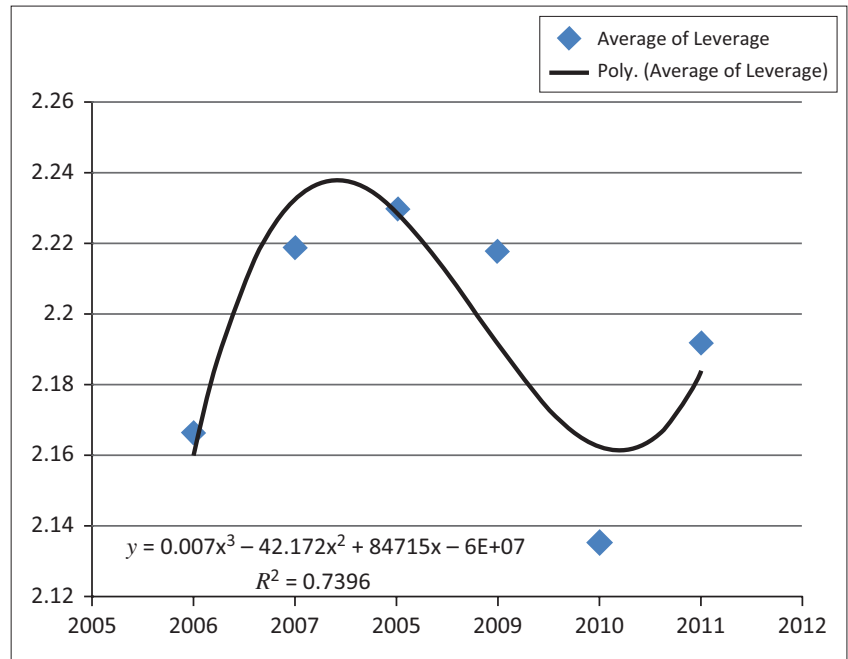

FIGURE 2: Leverage (mean).

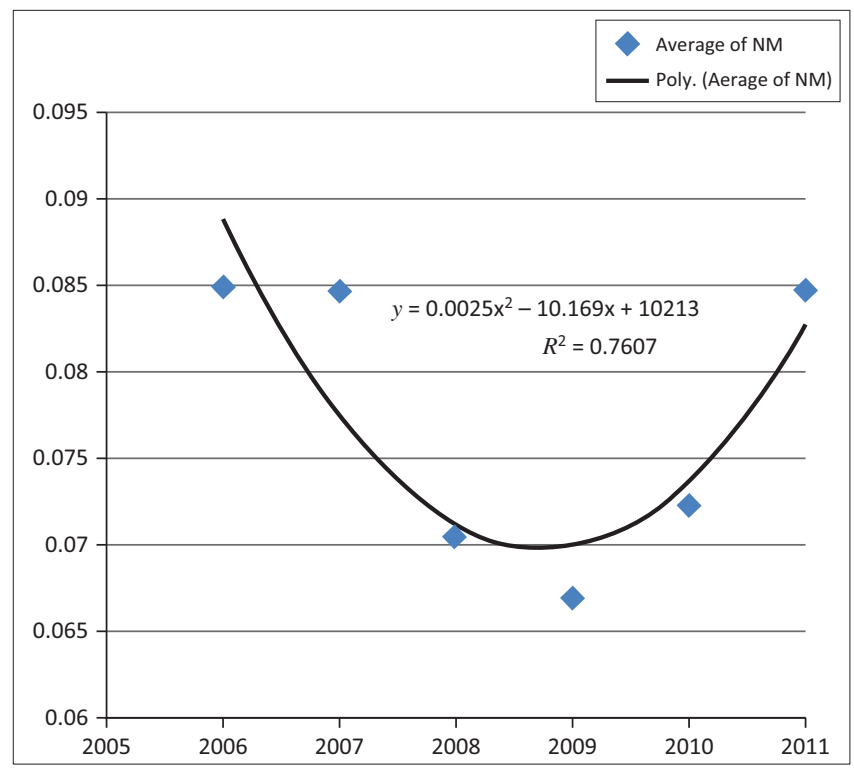

NM, net margin.

FIGURE 3: Net margin (mean).

From 2006 the net margin mean starts at 8.5\%, dips under $6.7 \%$ in 2009 and then slowly rises up towards pre-recession figures in 2011.

\section{Asset turnover}

It can be seen in Figure 4 that the progression over time of asset turnover (AT) does not follow a linear trend. It can be approximated by a cubic function with an $R^{2}$ of 0.6742 . $R^{2}$ is the measure of goodness of fit of the trend curve to the actual data and represents the average distance of the data points from the trend line. A perfect fit would have a value of 1 .

A slight upward trend from 2007 to 2009 is visible, with a sharp downward curve towards 2011.

\section{Return on equity}

The ROE measure (Figure 5) shows a clear quadratic trend, with a good fit of 0.8687 . The ROE across all 30 companies 


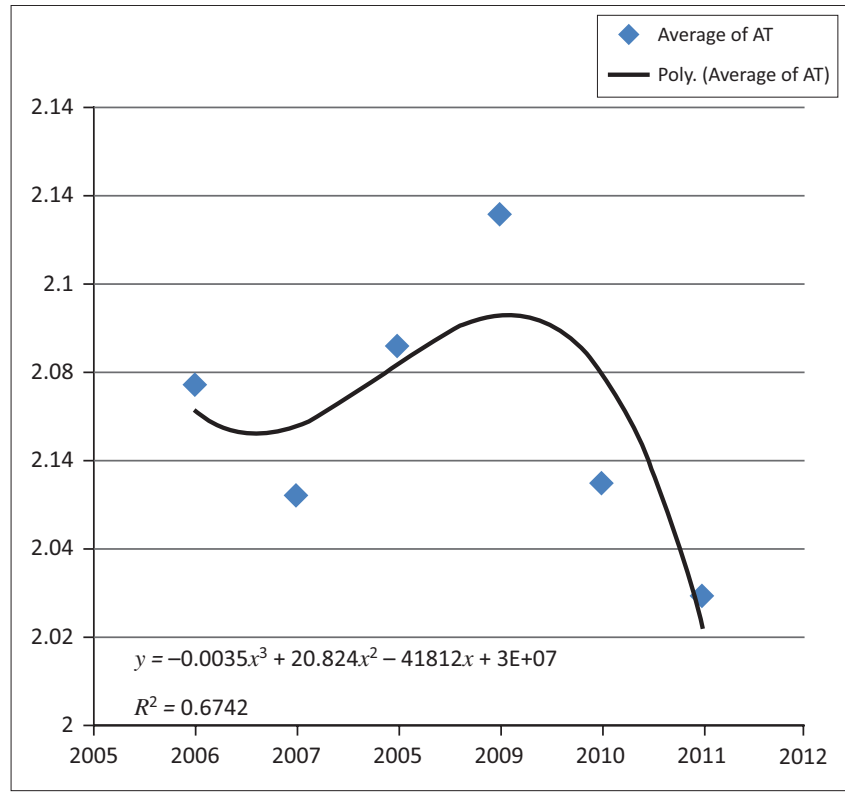

AT, asset turnover.

FIGURE 4: Asset turnover (mean).

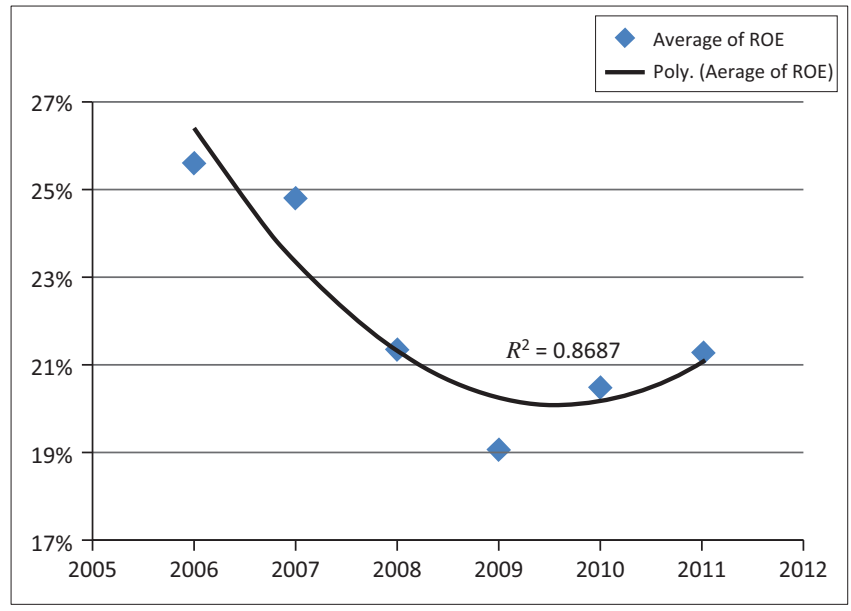

$R O E$, return of equity.

FIGURE 5: Return on equity (\%) (Mean).

decreased on average from 2006, with a recovery beginning to take place during 2009.

The ROE mean shows a clear downward trend from 2006 through 2011 and a slight upward curve towards 2011.

\section{CEO guaranteed cost to company}

$\mathrm{CEO}$ remuneration in this study was done by examining the guaranteed CTC for the CEO.

Table 4 shows the mean of the guaranteed CTC over the research period.

Standard deviation is calculated to show the variation or dispersion of the data from the mean calculated in Table 4, above. A low standard deviation shows that the data is close to the mean, with a large standard deviation explaining that the data is spread out further from the mean and from other data points.
TABLE 4: Cost to company mean ( $\left.\mathrm{R}^{\prime} 000\right)$.

\begin{tabular}{ll}
\hline Year & Cost to company \\
\hline 2006 & 2737.83 \\
2007 & 3049.70 \\
2008 & 3542.10 \\
2009 & 4065.10 \\
2010 & 4443.37 \\
2011 & 5026.10 \\
\hline
\end{tabular}

TABLE 5: Cost to company standard deviation ( $\left.R^{\prime} 000\right)$.

\begin{tabular}{ll}
\hline Year & Cost to company \\
\hline 2006 & 1974.87 \\
2007 & 2421.86 \\
2008 & 3142.65 \\
2009 & 4431.32 \\
2010 & 5504.45 \\
2011 & 6221.78 \\
\hline
\end{tabular}

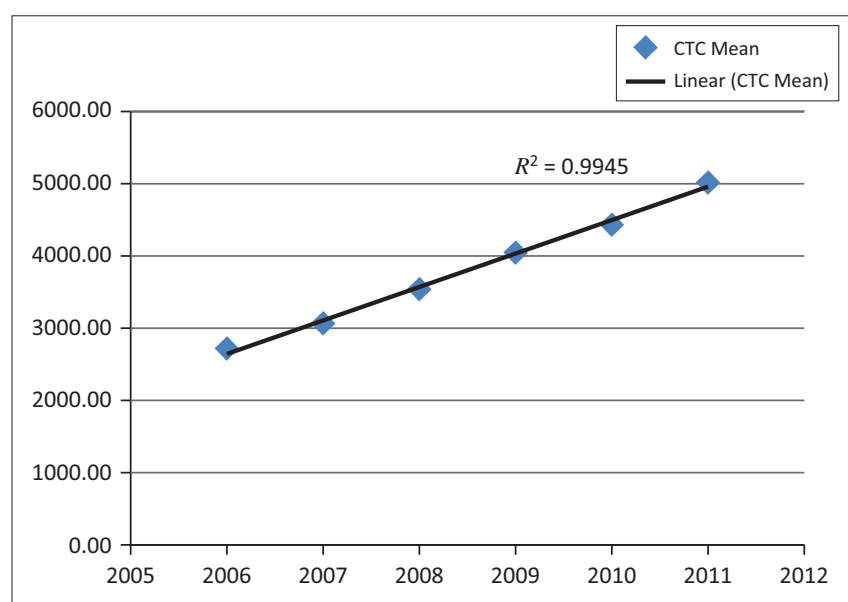

CTC, cost to company.

FIGURE 6: Cost to company mean ( $\left.R^{\prime} 000\right)$.

Table 5 shows the standard deviation for the guaranteed CTC of the CEOs during the research period.

A clear and distinctive upward linear line is visible on the CEO guaranteed CTC graph (Figure 6) over the research period.

The guaranteed CTC increase is at an average of $11.42 \%$ per annum over the research period.

The guaranteed CTC of the CEOs in this study showed a steady but significant increase of $11.42 \%$ over the research period. When this data is examined in conjunction with company financial performance it is clear that there is a difference in trend lines over the period researched. The results showed that CEO guaranteed CTC was not sensitive to the company financial performance during this period.

\section{Consumer price index}

The CPI as per Statistics SA (2012) can be summarised as illustrated in Table 6.

In Figure 7, the initial trend is upwards but a sharp downward curve is visible from the middle of 2008 to the middle of 2011. 
TABLE 6: Consumer price index.

\begin{tabular}{ll}
\hline Year & Consumer price index (\%) \\
\hline 2006 & 4.6 \\
2007 & 7.2 \\
2008 & 11.5 \\
2009 & 7.1 \\
2010 & 4.3 \\
2011 & 5 \\
\hline Source: Statistics South Africa, 2012, Stats SA: CPI, viewed 01 June 2012, from http://www.
\end{tabular}

Source: Statistics South Africa, 2012, Stats SA: CPI statssa.gov.za/keyindicators/CPI/CPIHistory.pdf

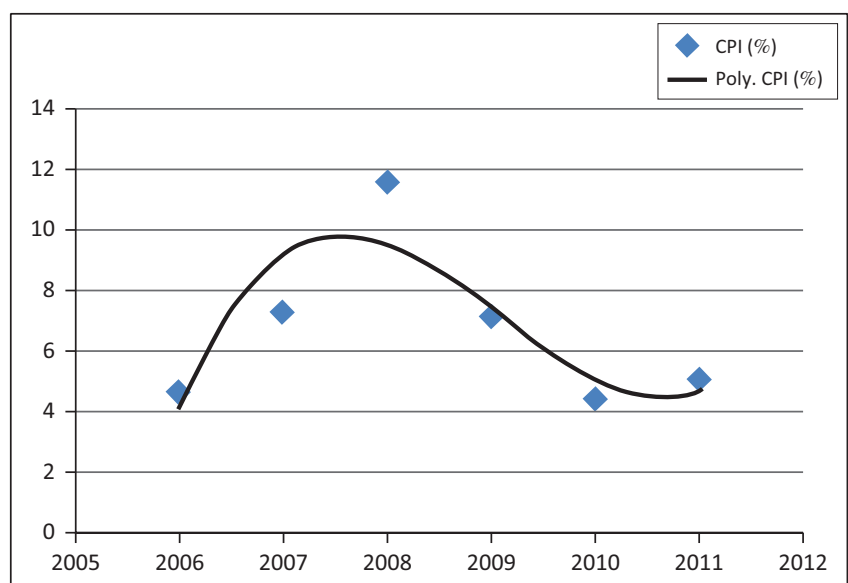

$\mathrm{CPI}$, consumer price index.

FIGURE 7: Consumer price index (\%)

TABLE 7: Cost to company mean, median, standard deviation.

\begin{tabular}{lllllll}
\hline Cost to company mean & $\mathbf{2 0 0 6}$ & $\mathbf{2 0 0 7}$ & $\mathbf{2 0 0 8}$ & $\mathbf{2 0 0 9}$ & $\mathbf{2 0 1 0}$ & $\mathbf{2 0 1 1}$ \\
\hline Mean & 2738 & 3050 & 3542 & 4065 & 4443 & 5026 \\
Median & 2226 & 2356 & 2562 & 2763 & 3087 & 3492 \\
Standard deviation & 1975 & 2422 & 3143 & 4431 & 5504 & 6222 \\
\hline
\end{tabular}

The CPI is an indication of the real price that the end consumer paid for a predetermined basket of goods over time and can be used as a measure of the increase in fixed remuneration per annum. The CPI showed an upward trend towards 2008 but decreased sharply from 2008.

\section{Guaranteed CTC before and after crisis}

Table 7 shows the mean, median and standard deviation for guaranteed CTC of the CEOs over the research period.

Figure 8 shows the clear upward trends for the guaranteed CTC mean from 2006 to 2008 and 2009 to 2011.

The two periods are compared to determine the correlation between the guaranteed CTC of the CEOs before and after the financial crisis.

\section{Research question 1}

A positive relationship between the financial performance of the company and the guaranteed CTC of the CEO was expected. A multiple regression analysis between each of the DuPont analysis constructs was done to investigate this relationship.

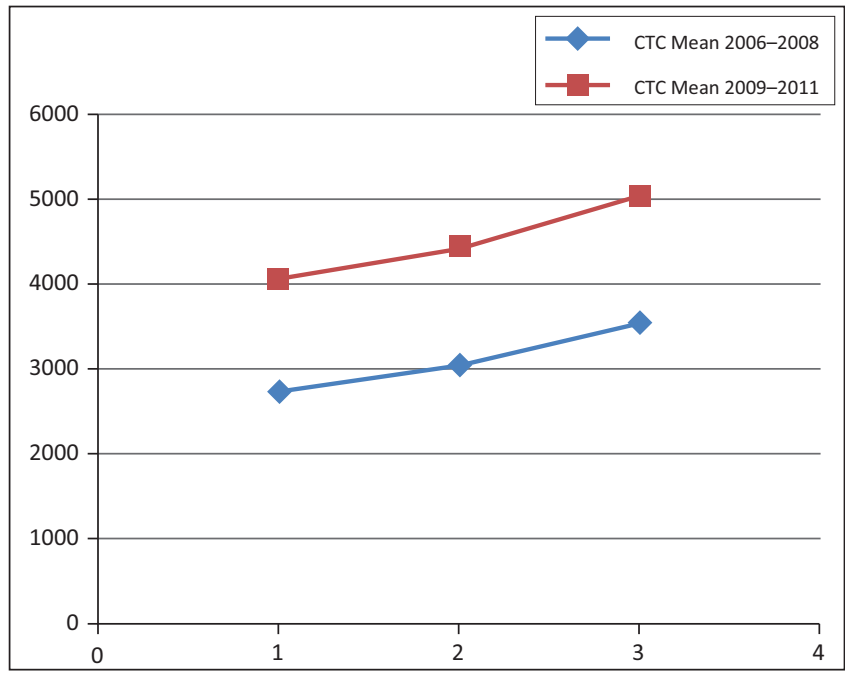

CTC, cost to company.

FIGURE 8: Cost to company mean (R'000) trends 2006-2008 and 2009-2011.

TABLE 8: Correlation and $r^{2}$ table for company financial performance and guaranteed cost to company.

\begin{tabular}{lccccccc}
\hline $\begin{array}{l}\text { Financial } \\
\text { Performance }\end{array}$ & 2006 & 2007 & 2008 & 2009 & 2010 & 2011 & Average \\
\hline Correlation & & & & & & & \\
Leverage & 0.037 & 0.043 & 0.175 & 0.075 & 0.072 & 0.002 & 0.068 \\
Net margin & -0.131 & -0.056 & -0.054 & -0.041 & -0.103 & 0.026 & -0.060 \\
Asset turnover & 0.180 & 0.099 & 0.097 & 0.184 & 0.251 & 0.135 & 0.158 \\
$\boldsymbol{r}^{\mathbf{2}}$ & & & & & & & \\
Leverage & 0.001 & 0.002 & 0.031 & 0.006 & 0.005 & 0.000 & 0.007 \\
Net margin & 0.017 & 0.003 & 0.003 & 0.002 & 0.011 & 0.001 & 0.006 \\
Asset turnover & 0.033 & 0.010 & 0.009 & 0.034 & 0.063 & 0.018 & 0.028 \\
\hline
\end{tabular}

Table 8 displays the correlation between company financial performance in terms of the DuPont analysis and CEO guaranteed CTC over the research period. The $r^{2}$ or coefficient of determination is included at the bottom.

The $r^{2}$ or coefficient of determination will always be between 0 and 1 and shows the percentage of variation of the dependent variable explained by the regression (Albright, Winston \& Zappe 2008). From Table 8 it is clear that there is a low correlation between company financial performance and CEO guaranteed CTC over the research period.

Figure 9 indicates the regression of the leverage construct on the CEO guaranteed CTC. Both means were used.

A clear negative relationship between the two variables is indicated by the linear trend line. A low $r^{2}$ is indicated.

Figure 10 depicts the negative relationship when the net margin mean is regressed on the guaranteed CTC mean. A low $r^{2}$ is indicated.

Figure 11 indicates the regression of the AT mean on the guaranteed CTC mean. A higher $r^{2}$ is achieved and the same negative relationship appears as with the first two constructs. 


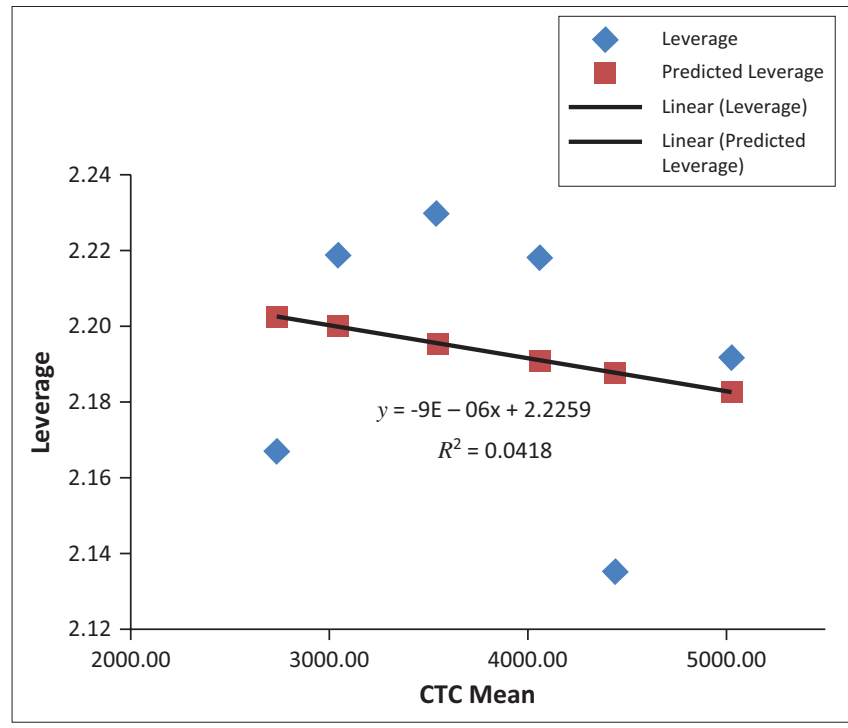

CTC, cost to company.

FIGURE 9: Regression of leverage mean on cost to company mean.

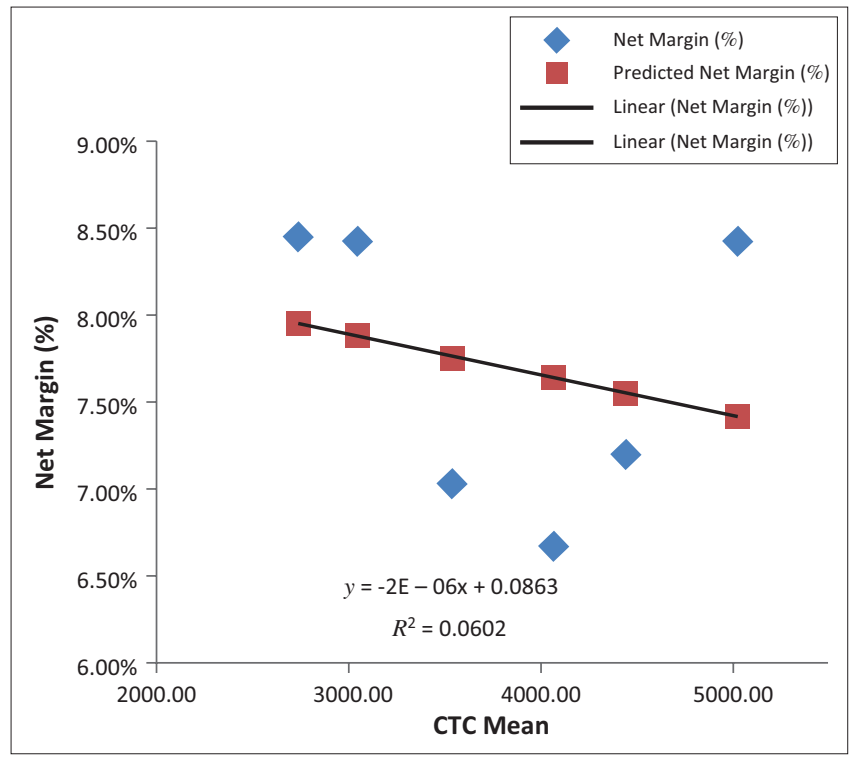

CTC, cost to company.

FIGURE 10: Regression of net margin mean on cost to company mean.

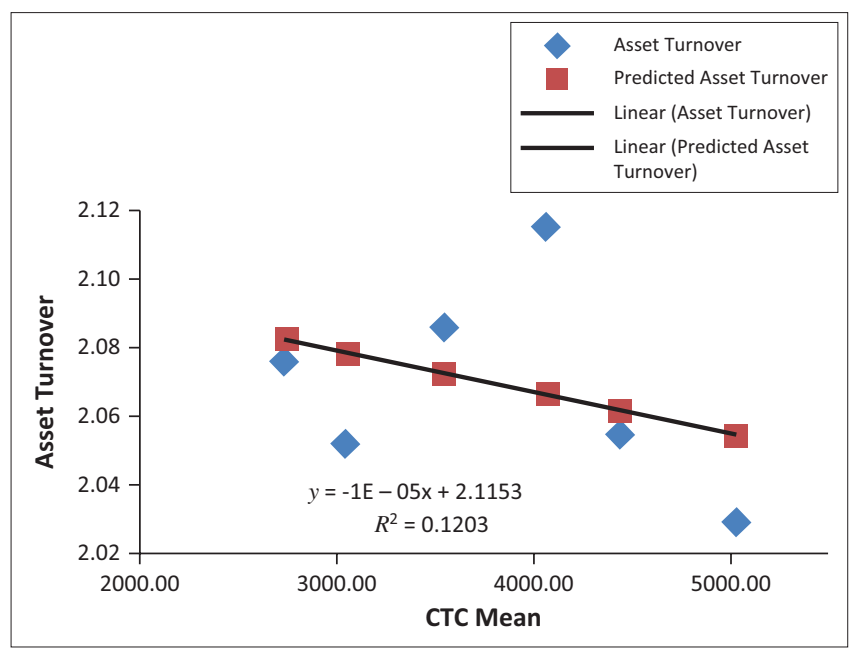

CTC, cost to company.

FIGURE 11: Regression of asset turnover mean on cost to company mean.
TABLE 9: Correlation and $r^{2}$ table - Guaranteed cost to company and return on equity (\%).

\begin{tabular}{lccccccc}
\hline Cost To Company & 2006 & 2007 & 2008 & 2009 & 2010 & 2011 & Average \\
\hline Correlation & & & & & & & \\
Return on equity & 0.057 & 0.089 & 0.158 & 0.290 & 0.303 & 0.180 & 0.179 \\
$\boldsymbol{r}^{2}$ & - & - & - & - & - & - & - \\
Return on equity & 0.00 & 0.01 & 0.03 & 0.08 & 0.09 & 0.03 & 0.041 \\
\hline
\end{tabular}

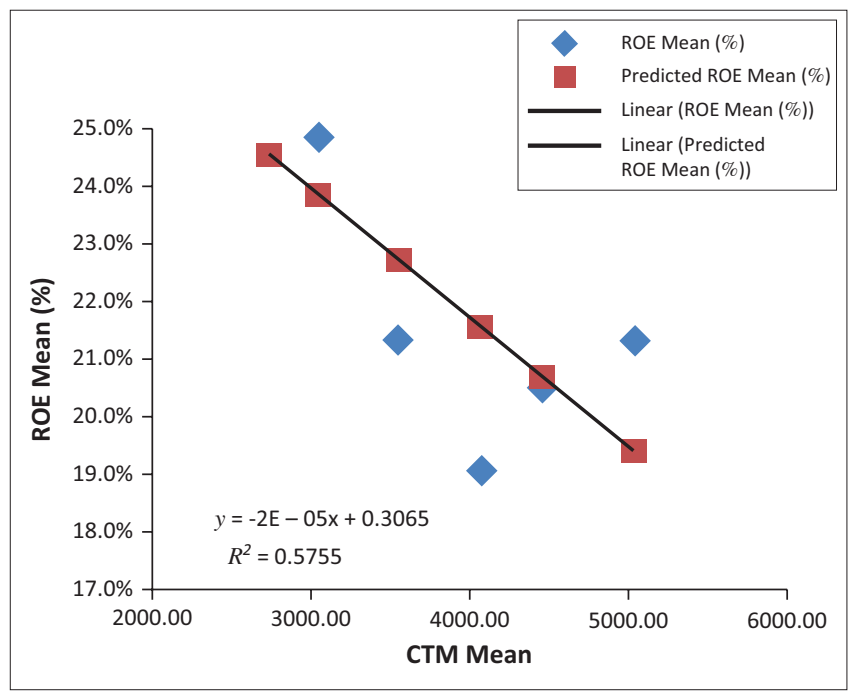

CTC, cost to company; ROE, return of equity.

FIGURE 12: Regression of the return on equity mean on the cost to company mean.

TABLE 10: Correlation and $r^{2}$ between the consumer price index and the cost to company.

\begin{tabular}{ll}
\hline Correlation & $r^{2}$ \\
\hline-0.24 & 0.061 \\
\hline
\end{tabular}

\section{Research question 2}

Question 2 relates to the correlation between the ROE, the product of the DuPont analysis and the CEO guaranteed CTC over the research period. Table 9 shows the correlation and $r^{2}$ coefficient of determination of these constructs.

The correlation is stronger between company financial performance in terms of ROE and CEO guaranteed CTC than for research question 1 but it is still weak.

In Figure 12 the ROE mean is regressed on the guaranteed CTC mean.

A clear negative relationship is indicated between the ROE mean and guaranteed CTC mean, with a strong $r^{2}$ relationship achieved.

\section{Research question 3}

In question 3 the relationship between the South African CPI and CEO guaranteed CTC before, during and after the financial crisis was analysed, to assess the possibility that an increase in the guaranteed CTC of the CEO, if any, is related to this construct. Table 10 shows a very low correlation and $r^{2}$ or coefficient of determination, for the CPI and guaranteed CTC. 


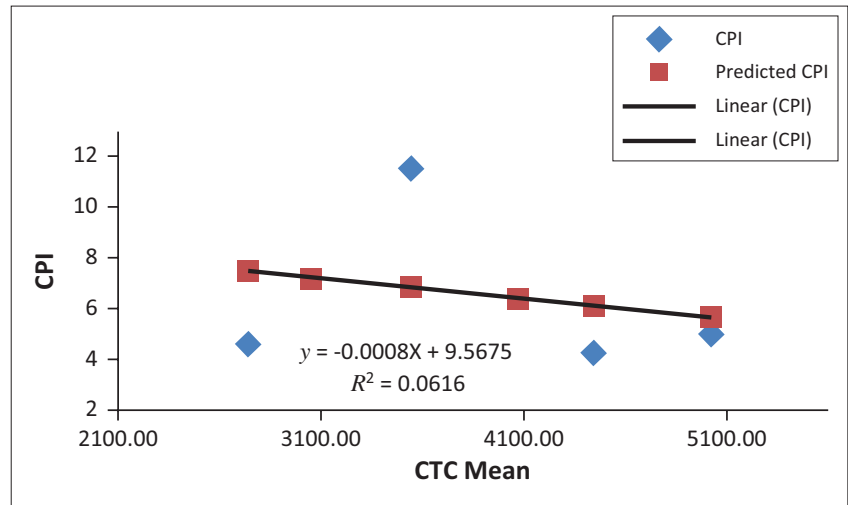

CTC, cost to company; $\mathrm{CPI}$, consumer price index.

FIGURE 13: Regression analysis of consumer price index and cost to company.

TABLE 11: Correlation and $r^{2}$ between cost to company mean of 2006-2008 and 2009-2011.

\begin{tabular}{ll}
\hline Correlation & $r^{2}$ \\
\hline 0.99998 & 0.99996 \\
\hline
\end{tabular}

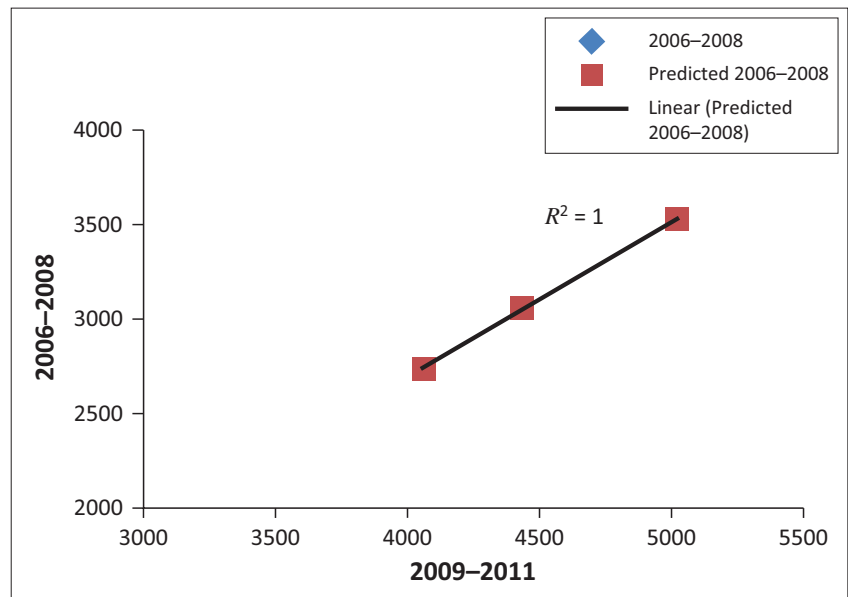

FIGURE 14: Regression of cost to company 2006-2008 (R'000) mean over cost to company 2009-2011 (R'000) mean.

A regression analysis was done and the negative relationship between the constructs is illustrated in Figure 13.

\section{Research question 4}

In research question 4, the aim was to determine the correlation between the guaranteed CTC of CEOs before the financial crises and after the financial crisis. This was done in order to determine the effect of the financial crisis on the guaranteed CTC of the CEOs. Table 11 shows the correlation and coefficient of determination between the guaranteed CTC of the CEO mean from 2006 to 2008 and guaranteed CTC of the CEO mean from 2009 to 2011.

A very strong correlation and $r^{2}$ are shown, explaining almost $100 \%$ of the variances detected in the analysis.

Figure 14 below shows the regression of the two constructs of research question 4 . The perfect correlation of the CTC 2006-2008 mean over the CTC 2009-2011 mean indicates that no change was made to the CTC of the CEOs during or after the global financial crisis in 2008.
TABLE 12: Summary of correlation and coefficient of determination.

\begin{tabular}{lcc}
\hline Determination & $\boldsymbol{R}$ & $\boldsymbol{r}^{2}$ \\
\hline Leverage & -0.20 & 0.042 \\
Net margin & -0.25 & 0.060 \\
Asset turnover & -0.35 & 0.120 \\
Return on equity & -0.76 & 0.575 \\
Consumer price index & -0.25 & 0.062 \\
\hline
\end{tabular}

The regression analysis of the mean of guaranteed CTC 20062008 over the mean of guaranteed CTC 2009-2011 shows a positive relationship with a high $r^{2}$ describing most of the variances between the constructs.

\section{Summary of results}

Each of the measures of company financial performance, the CPI and the guaranteed CTC of the CEO returned a high coefficient of determination scores, indicating a good linear fit in the data. In question 1 and question 2, the clear negative relationship between the regressed means of the measurements of financial performance and that of the guaranteed CTC of the CEO is evident, although it shows a relatively low coefficient of determination between the constructs of the DuPont analysis.

Question 3 returned another low determinant of coefficient and as with the first two questions, the regression relationship between the constructs is negative. The guaranteed CTC of the CEOs over the research period showed a steady and significant increase. This showed the CEOs' guaranteed CTC as not being sensitive to company financial performance or the CPI. The CPI did not seem to have an influence on the guaranteed CTC of the CEOs, as the relationship showed a negative trend.

Table 12 summarises the correlation and coefficient of determination for leverage, net margin, AT, ROE and CPI with the guaranteed CTC of the CEOs.

The relationship between the guaranteed CTC before and after the financial crisis is strong with a very high coefficient of determination and a positive relationship.

\section{Discussion of results}

\section{Research question 1}

The aim of research question 1 was to investigate the possible relationship between the individual constructs of the DuPont analysis and the guaranteed CTC of the CEOs over the research period.

\section{Leverage}

The relationship between leverage and guaranteed CTC was tested through correlation and regression analysis. Leverage had a weak coefficient of determination or $r^{2}$ which shows that on average only $0.7 \%$ of the variation between leverage and guaranteed CTC could be explained by the linear relationship (Albright et al. 2008). Mean of leverage was regressed over the mean of guaranteed CTC of the CEO; 
a negative relationship was noted. A negative correlation means that the variables being analysed are moving in opposite directions (Urdan 2010).

\section{Net margin}

The relationship between the net margin and guaranteed CTC was also tested through correlation and regression analysis. The correlation coefficient produced a small number $(0.6 \%)$, thus explaining only a negligible portion of the variance between the constructs regressed. The regression analysis of the mean of net margin over the guaranteed CTC mean delivered a negative relationship between the constructs. This negative relationship shows that as company margins decreased over the economic recession period, the guaranteed CTC of the CEOs increased. This surprising result indicates that the guaranteed CTC is insensitive to the margins of the company.

\section{Asset turnover}

The coefficient of determination was returned at $12 \%$ and reflected a negative relationship between guaranteed CTC and AT. The productivity of the assets decreased during the period of the economic slowdown and this could be attributed to a decrease in sales and the inability of the management of the companies to apply the assets efficiently.

The negative relationship between all three constructs of the DuPont analysis and the guaranteed CTC of the CEOs is unexpected. The insensitivity of the guaranteed CTC of the CEOs to the constructs measured by the DuPont analysis is problematic as all three constructs can be managed by the CEO and point to the performance of the CEO. The performance of the $\mathrm{CEO}$ and the financial performance of the company did not influence the guaranteed CTC of the CEO.

\section{Research question 2}

Research question 2 related to the correlation between guaranteed CTC of the CEO and ROE. The coefficient of determination of the regression of the ROE mean over the mean of guaranteed CTC is very strong, indicating that $57 \%$ of the variances can be explained. The regression line indicates a negative relationship between the mean of ROE and the mean of guaranteed CTC, with a strong $r^{2}$ explaining a substantial amount of the relationship. The negative relationship between the two constructs is alarming, as it indicates that ROE and CEO effectiveness did not influence the guaranteed CTC of CEOs over the research period.

\section{Research question 3}

The purpose of research question 3 was to investigate the relationship between the CPI and the guaranteed CTC of the CEOs over the research period. A very weak $r^{2}$ was returned $(6 \%)$ and a negative relationship was evident within the correlation of the CPI and the guaranteed CTC of the CEOs. The increase in guaranteed CTC of the CEOs over the research period outperformed the CPI.

\section{Research question 4}

The aim of research question 4 was to divide the guaranteed CTC of CEOs into two periods and investigate the relationship between the two periods. This was done to observe the effect of the financial crisis on the guaranteed CTC of the CEOs. The correlation and coefficient of determination returned very strong values during the regression of the 2006-2008 period and over the 2009-2011 period. There is also a positive trend visible in the regression. The financial crisis of $2008 \mathrm{had}$ no effect on the guaranteed CTC of the CEOs and the trend before and after the crisis stayed the same.

\section{Summary of discussion}

Analysing the research questions independently and together led to a better understanding of the constructs that influence the guaranteed CTC with which the CEOs burden their companies. The levers that make up the DuPont analysis, leverage, net margin and AT, showed a weak correlation but a negative relationship was noted for all three constructs. This shows that whilst the financial performance of the companies was under pressure during the financial crises in 2008, the guaranteed CTC of the CEOs increased.

The ROE, which shows the ability to produce returns to the shareholders, was found to have a high correlation and a negative relationship to the guaranteed CTC of the CEOs. The companies were not able to produce high returns during the research period but their CEOs' CTC remained unaffected. The discussion of the principal-agent theory begs the question, do the CEOs, as agents for the principal, have the interests of the principal at heart? This research showed that CEOs are able to increase their guaranteed CTC regardless of the ROE of the company.

From the literature the researcher's expectation was that the financial performance of the company would not have a strong relationship with the guaranteed CTC of the CEO but that the policy used to calculate the guaranteed CTC of the CEO would be influenced by the financial crisis of 2008 and that the increase in guaranteed CTC of the CEO would level off. From the results, it can be seen that this was not the case.

The CPI has long been used as a measure of salary increases; however, from the results, it is apparent that no relationship between the CPI and guaranteed CTC of the CEOs could be found.

Research question 4 returned a strong coefficient of determination when the guaranteed CTC of the CEOs was broken up into two periods: immediately before the financial crisis and immediately after the financial crisis. A positive relationship trend was evident in the regression and it can be argued that the financial crisis did not influence the guaranteed CTC of the CEO. From the discussion of managerial power it can be argued that the CEOs used their influence and power to ensure that the guaranteed CTC construct of their total 
remuneration was not negatively influenced in the same way as their short-term incentives by the financial crisis. From the results, it seems that the guaranteed CTC of the CEOs in the retail and consumer goods sector was not sensitive to the financial performance of the companies in terms of DuPont analysis during the economic downturn of 2008.

\section{Conclusion}

DuPont analysis showed that the financial performance of companies had little or no effect on the guaranteed CTC of the CEOs. The managerial power of the CEOs and the principal-agent theory could explain the increase in their guaranteed CTC, which was misaligned with the financial performance of the companies over a time period that saw one of the biggest global financial crises.

The guaranteed CTC of the CEO should be reduced due to the financial performance of the company and pursuant to the contractual nature of the employment agreement between a company and its CEO. It stands to reason that the misalignment of the company's financial performance and the various constructs of remuneration would lead to discontentment for the various shareholders and employees.

\section{Recommendations}

The following recommendations can be made:

- The relationship between company-specific financial performance and guaranteed CTC of the CEO must be clearly defined to ensure alignment of the two constructs.

- Measures of CEO performance need to be communicated and their remuneration should be clearly linked to these measures to ensure future company performance due to CEO intervention.

- The competence and independence of the remuneration committee needs to be ensured to minimise managerial power from the $\mathrm{CEO}$ in times when short-term incentives are difficult to attain.

- The measures for company financial performance need to be set in line with measures of CEO performance and be aligned with shareholder expectations.

\section{Areas for future research}

There are various other measures of company financial performance that could be explored such as earnings before interest, taxes, depreciation and amortization (EBITDA), debt to asset value and pure company valuation techniques.

Short- and long term incentives could be explored in terms of company financial performance measures using the various other measures available.

A comparison of the remuneration of CEOs in developed countries and the financial performance of these companies over the research period could be compared to that of South African companies in the same sector.

\section{Acknowledgements Competing interests}

The authors declare that they have no financial or personal relationship(s) that may have inappropriately influenced them in writing this article.

\section{Authors' contributions}

M.B. (University of Johannesburg) was the principle investigator and was responsible for the design and execution of the project and writing the article. M.N. (University of Pretoria) was responsible for field work and writing up the research.

\section{References}

Albright, S.C., Winston, W.L. \& Zappe, C.J., 2008, Data analysis \& decision making with Microsoft Excel, South-Western Cengage Learning, Mason, $\mathrm{OH}$.

Bussin, M., 2011, The remuneration handbook for Africa: A practical and informative handbook for managing and recognition in Africa, Knowres Publishing, Randburg.

Bussin, M., Makhubela, K. \& Quail, N., 2009, The impact of recession on global pay', viewed 06 February 2012, from www.21century.co.za

21st Century Pay Solutions Group, (2011), Total reward - How does it work?, viewed 09 February 2012, from http://www.21century.co.za/images/stories/21st_ Century_Total_Reward_Offering_2011.pdf

Doscher, T. \& Friedl, G., 2010, 'Corporate governance, stakeholder power and executive compensation', OR Spectrum 33, pp. 309-331. http://dx.doi.org/10.1007/s00291 010-0218-z

Duffhues, P. \& Kabir, R., 2007, 'Is the pay-performance relationship always positive? Evidence from the Netherlands', Journal of Multinational Financial Management 18, 45-60. http://dx.doi.org/10.1016/j.mulfin.2007.02.004

Ellig, B.R., 2007, The complete guide to executive compensation, McGraw-Hill, New York, NY.

Elliott, L., 2011, Fears over high street 'paralysis' as financial crisis hits retail sales hard, viewed 09 February 2012, from http://www.guardian.co.uk/business/2011/ aug/08/recession-fears retail

Englund, M. \& MacDonald, R., 2008, Financial crisis slams retail, manufacturing viewed 09 February 2012, from http://www.businessweek.com/investor/content/ oct2008/pi20081015_679094.htm

Frydman, C. \& Jenter, D. 2010, 'CEO compensation', Annual Review of Financial Economics 2, 75-102. http://dx.doi.org/10.1146/annurev-financial-120209-133958

Harvey, C., 2012, 'Optimal contract', The Free Dictionary by Fairelex. viewed n.d., from http://financial-dictionary.thefreedictionary.com/Optimal+Contract

Heim, J., 2011, Executive Pay Circa, viewed 09 February 2012, from www. financialexecutives.org

Higgins, R.C., 2009, Analysis for financial management, McGraw Hill, Singapore.

Hoi, C.-K. \& Robin, A., 2004, 'The design of incentive compensation for directors', Corporate Governance 4(3), 47-53. http://dx.doi.org/10.1108/ 14720700410547495

JSE, 2013, JSE Listing Requirements, viewed 03 December 2014, from http://www.jse. co.za/Libraries/Listing_requirements_Continuing_obligations_checklist/Annual_ Report_requirements.sflb

King Committee, 2009, King report on governance for South Africa 2009, King Committee, South Africa.

Laffont, J.-J. \& Martimort, D., 2002, The theory of incentives, the principal-agent model, Princeton University Press, Princeton, NJ.

Little, P.L., Little, B.L. \& Coffee, D., 2009, 'The Du Pont model: Evaluation alternative strategies in the retail industry', Academy of Strategic Management Journal 8, 71-79.

McGregor, B.F.A., 2011, Directors remuneration, viewed 12 July 2012, from http://0-secure.mcgbfa.com.innopac.up.ac.za/Station/DirectorsRemuneration/ DirectorsRemunerationDetails.aspx

O'Reilly, C. \& Main, B.G., 2010, 'Economic and psychological perspectives and CEO compensation: A view and synthesis', Industrial and Corporate Change 19(3), 675-712. http://dx.doi.org/10.1093/icc/dtp050

Rollins, J.R., 2006, 'Lies, damn lies and statistics', Public Utilities Fortnightly (September), 47-48, viewed n.d., from http://www.fortnightly.com/fortnightly/2006/09/liesdamn-lies-and-statistics

Saunders, M. \& Lewis, P., 2012, Doing research in business \& management, Prentice Hall, Harlow, England.

Soliman, M.T., 2008, 'The use of DuPont analysis by market participants', The Accounting Review 83(3), 823-853. http://dx.doi.org/10.2308/accr.2008.83.3.823

Statistics South Africa, 2012, Stats SA: CPI, viewed 01 June 2012, from http://www. statssa.gov.za/keyindicators/CPI/CPIHistory.pdf

Urdan, T.C., 2010, Statistics in plain English, 3rd edn., Routledge, New York, NY. 